\title{
The lethal and sub-lethal consequences of entomopathogenic nematode infestation and exposure for adult pine weevils, Hylobius abietis (Coleoptera: Curculionidae)
}

\author{
R.D. Girling *, D. Ennis, A.B. Dillon, C.T. Griffin \\ Department of Biology, Institute of Bioengineering and Agroecology, NUI Maynooth, Maynooth, Co. Kildare, Ireland
}

\section{A R T I C L E I N F O}

\section{Article history:}

Received 30 November 2009

Accepted 5 April 2010

Available online 9 April 2010

\section{Keywords:}

Hylobius abietis

Steinernema carpocapsae

Heterorhabditis downesi

Feeding behavior

Biological control

$\mathrm{LT}_{50}$

$\mathrm{LT}_{90}$

\section{Introduction}

The large pine weevil, Hylobius abietis Linnaeus, is the major economic threat to reforestation in Europe (Leather et al., 1999; Langstrom and Day, 2004). In North America its niche is filled by two species from the same genus, Hylobius congener Dalla Torre (Martin, 1964) and Hylobius pales Herbst (Coleoptera: Curculionidae) (Lynch, 1984). It is the adult weevils that cause the financial damage, by feeding on and killing replanted seedlings (Orlander and Nilsson, 1999). This feeding not only causes seedling mortality but also reduced growth and stem deformation (Eidmann et al., 1996). It was estimated in 2004 that if pesticides were not used the cost of the resulting damage across Europe would be approximately $€ 140$ million per year (Langstrom and Day, 2004).

Female adult weevils lay their eggs on or nearby tree stumps and other recently dead or dying wood (Scott and King, 1974; Nordenhem and Nordlander, 1994; Nordlander et al., 1997). Larvae develop in the stumps, living and feeding just under the bark. They pass through four larval moults over a period of 12-36 months prior to pupation and emergence of adults (Leather et al., 1999).

* Corresponding author. Present address: School of Biological Sciences, University of Southampton, Boldrewood Campus, Southampton SO16 7PX, UK. Fax: +44 (0) 2380594459.

E-mail address: robbie_girling@hotmail.com (R.D. Girling).
Clear felling a forest creates many tree stumps, which provide an excellent habitat for the development of larval $H$. abietis. Stumps remain a useable resource for $H$. abietis larvae for up to 3 years after felling (Nordenhem, 1989). Large population levels can build up in an area due to the continual provision of breeding material provided by rotational harvesting of forests within the weevils' dispersal range (Nordlander, 1987). The adults feed on the bark and cambium of live trees, commonly that of young seedlings (replants used to restock the site). Adult feeding can drastically reduce the numbers of young replants, by in some cases up to $100 \%$, due to the high population densities of weevils on a site relative to the available feeding material (Tilles et al., 1986). Therefore, seedling death can either occur due to the sheer volume of feeding damage or when weevil damage forms a complete ring around the stem, killing the plant. Seedlings can be susceptible to weevil attack for the first 2-3 years following restocking (Petterson et al., 2005). Furthermore, adult weevils are extremely mobile, with high dispersal ability, and can therefore cause damage over a broad area (Solbreck, 1980).

Currently, the main method of control of H. abietis in Ireland and the UK is by the use of pesticides. These controls include the treatment of seedlings with the pyrethroids cypermethrin or $\alpha$ cypermethrin. It is likely that the European Union will look to increase its current restrictions on the use of pesticides in forestry (Georgis et al., 2006). Currently, H. abietis is the only insect pest 
in forestry in the UK and Ireland against which pesticide is routinely applied (Willoughby et al., 2004). As a possible alternative, entomopathogenic nematodes (EPN) have been trialed for the biological control of H. abietis (Pye and Pye, 1985; Brixey, 2000; Brixey et al., 2006; Dillon et al., 2006, 2007; Torr et al., 2007). EPN in the families Steinernematidae and Heterorhabditidae are lethal parasites of a broad variety of insect species (Poinar, 1979). These EPN have a symbiotic association with bacteria of the genera Xenorhabdus and Photorhabdus, respectively, which are in part the cause of their pathogenicity (Forst et al., 1997). Non-feeding infective juveniles (IJs) search for insect hosts in the soil and infect the insect by entering through its natural openings, mainly the mouth, anus, spiracles and also through the cuticle (Mràcek et al., 1988; Peters and Ehlers, 1994). Once in the hemolymph the IJs release their symbiotic bacteria from their gut, which proliferate, killing the insect. The nematodes develop and reproduce inside the insect cadaver and produce more IJs that emerge from the cadaver within 1-3 weeks and search out new hosts for infection. The use of EPN against $H$. abietis has been directed at both their larval and pupal stages (Dillon et al., 2006, 2007), and their pupal and callow adult stages (Brixey et al., 2006) whilst still in the stumps, but all stages, including adults, are susceptible to EPN infection (Pye and Burman, 1978; Pye and Pye, 1985; Brixey, 2000). The population of $H$. abietis on a clearfell site $2-3$ years after felling consists of the indigenous weevil population (those which developed in the stumps and survived control measures on that site) and the migrant population (adult weevils attracted into the area by nearby felling). Under sustainable forest management, as per Forest Stewardship Council guidelines, there has been a move away from large felling coupes, with smaller felling coupes preferred. While smaller felling coupes may be environmentally advantageous in terms of soil and water protection, continuous felling in a forest property may increase the size of the migrant $H$. abietis population, as volatiles are continuously emitted during the prolonged felling period. As it is not always possible to treat all felling coupes within a forest property (e.g. steep sites preclude the use of the machinery used to apply the nematodes), EPN applied in a biocontrol program should ideally kill the immature weevils developing in the stumps and also kill or reduce feeding by the migrant/emerging adult weevils. Furthermore, field trials have been conducted where seedlings and their surrounding soil were dipped in a suspension of Steinernema carpocapsae, which significantly reduced seedling mortality (Pye and Pye, 1985). Little consideration has been given to the effects, both lethal and sub-lethal, that EPN may have on adult $H$. abietis.

While the main aim of using EPN in biological control is to kill the target insect, infection with EPN of both adult and larval stages of insects has also been shown to have sub-lethal effects. For example, mature Spodoptera littoralis larvae fed with Steinernema riobrave had decreased rates of leaf consumption and ate fewer meals in comparison to control treatments (Alchanatis et al., 2000). Additionally, Simões et al. (2000) showed that Galleria melonella infected with $S$. carpocapsae had reduced silk production. Chemical insecticides also have sub-lethal effects on insects, including on H. abietis (Rose et al., 2006). However, it has not previously been investigated whether exposure of $\mathrm{H}$. abietis to sublethal concentrations of EPN has behavioral effects on the insect. If infection/exposure with EPN were to affect the behavior of $H$. abietis, such as reducing their feeding rate, then it would make EPN an even more effective biological control agent.

Therefore, in the current study we compared the lethal and sub-lethal effects of two EPN species, S. carpocapsae and Heterorhabditis downesi, which have different foraging strategies, on adult $H$. abietis. EPN can be classified in terms of their foraging behavior, being ambush, cruise or intermediate foragers (Campbell and Gaugler, 1993). S. carpocapsae is classed as an ambush forager and is reported to remain near the soil surface where it attaches onto passing mobile hosts. Heterorhabditis spp. are classified as cruise foragers, ranging widely and responding to volatiles from sedentary hosts (Campbell and Gaugler, 1993). However, this classification should not be given undue weight, as shown by fact that $S$. carpocapsae were able to infect pine weevils within tree stumps at depths of more than $30 \mathrm{~cm}$ below soil surface (Dillon et al., 2006). To investigate lethal effects of EPN on $H$. abietis, we exposed adult weevils to a range of concentrations of IJs and determined the percentage mortality and speed of kill ( $\mathrm{LT}_{50}$ and $\mathrm{LT}_{90}$ values). To investigate sub-lethal effects we tested whether exposure to and infestation by EPN affected $H$. abietis feeding rate on bark disks. In addition, to examine whether EPN could be used to protect tree seedlings against adult weevil feeding, we exposed weevils to EPN and measured the weevils feeding rate on live seedlings.

\section{Materials and methods}

\subsection{Insects}

For all experiments, adult $H$. abietis weevils were collected from pine, Sitka spruce and larch tree stumps, from sites across Ireland. Weevils were collected using emergence traps set over stumps (Dillon et al., 2006), which were emptied every 2 weeks between ca. June-November 2007. After collection, weevils were maintained in the laboratory in plastic Tupperware boxes containing a freshly cut piece of Sitka spruce branch (for food) and moist tissue paper, which were both replaced on a weekly basis, or when all bark had been consumed. Boxes were kept in a constant temperature room at $20^{\circ} \mathrm{C}$.

\subsection{Nematodes}

S. carpocapsae All strain and H. downesi K122 were produced in late instar larvae of the greater wax moth Galleria mellonella (L.), at $20^{\circ} \mathrm{C}$ (Woodring and Kaya, 1988). Nematode-killed insects were placed on White traps. IJs were harvested daily for 3 days from the time of first emergence and harvests were pooled. Harvested IJs were washed by sedimentation in three changes of tap water and stored for up to 3 months at $9^{\circ} \mathrm{C}$. Storage was in $50 \mathrm{ml}$ aliquots $(2000 \mathrm{IJs} / \mathrm{ml})$ in $9 \mathrm{~cm}$ diameter food containers with snap-on lids.

\subsection{Pathogenicity of EPN for adult H. abietis}

An attempt was made to simulate how weevils may be exposed to EPN in forestry biocontrol programmes, where nematodes are sprayed on and around tree stumps and adult weevils emerging from stumps would need to move through the soil, which is frequently peat-based. Weevils were buried in peatmoss compost within $50 \mathrm{~mm} \times 17 \mathrm{~mm}$ bijou screw-cap tubes, one weevil per tube. The compost was packed so that the weevil was surrounded by soil at all times. IJs of either $H$. downesi or $S$. carpocapsae were applied to the top of the compost before the lid was closed. For each nematode species the following concentrations of IJs were applied: 500, 1000, 2000, and 4000 in $500 \mu \mathrm{l}$ of water. In addition, a water control was included. For each nematode and concentration combination ten weevils were tested and the whole experiment was repeated three times. Tubes were placed in a constant temperature room at $20^{\circ} \mathrm{C}$ for $12 \mathrm{~h}$, after which the weevils were removed and placed individually in wells of 24-well multiwell tissue-culture plates, containing moist filter paper. Weevils were then checked daily for mortality, for 10 days. Data from the three replicates were pooled to calculate $\mathrm{LT}_{50}$ and $\mathrm{LT}_{90}$ values by probit analysis. 


\subsection{Effects of EPN on feeding by adult H. abietis: Bark disk experiment}

Weevils were initially exposed to nematodes: they were placed in 24-well multiwells, one weevil per well, containing a $1 \mathrm{~cm}$ circle of filter paper, treated with one of five treatments: (1) $50 \mu$ l of water (no nematodes); (2) 400 IJs of $S$. carpocapsae (low concentration); (3) 2000 IJs of S. carpocapsae (high concentration); (4) 2000 IJs of H. downesi (low concentration); or (5) 10,000 IJs of H. downesi (high concentration). Nematodes were applied in $50 \mu \mathrm{l}$ of water. Weevils were left for $24 \mathrm{~h}$ in the wells with no access to food. Trial experiments, using this experimental procedure, demonstrated that these concentrations resulted in approximately equivalent killing rates for the two EPN species, at both the high and low concentrations.

For the feeding assay, food containers $(9 \mathrm{~cm}$ diameter by $5 \mathrm{~cm}$ high) with snap-on lids were filled with ca. $50 \mathrm{~g}$ of dry sterile sand. Disks of bark, with a diameter of $10 \mathrm{~mm}$, were punched from a freshly cut Sitka spruce trunk, using a metal corer, and a single disk was placed in the center of a food container, as a food source for the weevils. One weevil was then added to each food container. Bark disks were removed and replaced by fresh ones every day and were weighed both before being put into the food containers, and on their removal. On removal the disks were also checked for visible evidence of feeding. Two experiments were conducted. In the first 40 blocks were tested, and in the second 20 blocks were tested. Each block contained one replicate of each of the five treatments plus a control treatment, which consisted of only a bark disk with no weevil in the food container. The first experiment was conducted for 5 days, with bark disks weighed every day. The second experiment was conducted over six days with bark disks being weighed only on days 1,2 , and 6 . All weevils were dissected at the end of each experiment to check for live, dead or encapsulated nematodes. Experiments were conducted in a constant temperature room at ca. $20^{\circ} \mathrm{C}$ under a L16:D8 light regime.

\subsection{Effects of EPN on feeding by adult $H$. abietis: seedling experiment}

An experiment was conducted to investigate whether exposing $H$. abietis to EPN would protect tree seedlings against adult $H$. abietis feeding, by reducing adult feeding rates. Containerised Sitka spruce seedlings, standardized to be of approximately equal size (mean height $23 \mathrm{~cm}$ ), were transplanted into $9 \mathrm{~cm}$ plant pots containing peat-moss compost and acclimated for 1 week at $17^{\circ} \mathrm{C}$. Individual seedlings were treated with a suspension of 3000 , 30,000 , or 300,000 IJs per plant of either S. carpocapsae or H. downesi, which was applied to the surface of the peat-moss around the base of the seedling in $5 \mathrm{ml}$ of water. Eidt et al. (1995) recommended an application rate of 300,000 IJs per seedling for control of $H$. congener. Control seedlings were treated with $5 \mathrm{ml}$ of water. Twenty-four hours after nematode application, either 1 or 3 adult weevils were introduced into the arena. In order to ensure weevils remained at the seedling, individual seedlings were placed in an enclosure ( $45 \mathrm{~cm}$ height, $10 \mathrm{~cm}$ diam.), which slotted into the top of the pot. The enclosure was constructed using a 21 plastic bottle, including a $7 \mathrm{~cm}$ strip of wire mesh encircling the bottle, to provide ventilation to prevent excessive moisture due to high humidity. Weevils were allowed to feed for 6 days, after which time they were removed and the area of bark consumed was measured using image analysis software (Image Pro, Media Cybernetics, MD, USA). Nine blocks were tested, and each block contained 1 replicate of each of the 14 treatments (two nematode species at three concentrations and a water control at both weevil densities).

\subsection{Statistics}

$\mathrm{LT}_{50}$ and $\mathrm{LT}_{90}$ values for the bioassay were obtained by Probit analysis, assuming a Weibull distribution of data, using MINITAB v. 14.0 (Minitab Inc., State College, Pa., USA). These values were calculated using only the data for insects that died during the course of the 10 day experiment, rather than for all of the insects that were exposed. Therefore, the $\mathrm{LT}_{50}$ and $\mathrm{LT}_{90}$ values are the times taken for $50 \%$ and $90 \%$ of individuals to die of those individuals that died within 10 days. In comparisons between nematode species, of $\mathrm{LT}_{50}$ and $\mathrm{LT}_{90}$ values for all concentrations, two values were considered different if their 95\% confidence intervals did not overlap.

All comparisons of probability data were made using $\chi^{2}$ tests, with Yate's correction for continuity and Bonferroni's correction for multiple tests made where necessary. A series of GLMs was performed to compare weevil feeding, for both disk feeding and seedling feeding data, using MINITAB v.14.0. Data for the disk feeding and seedling feeding experiments were tested for normality and data found to be non-normal were transformed before analysis.

\section{Results}

\subsection{Pathogenicity of EPN for adult $H$. abietis}

By day $10, S$. carpocapsae killed significantly more $H$. abietis than H. downesi at all nematode concentrations (Table 1). Within S. carpocapsae treatments highest mortality (93.3\%) occurred at the $2000 \mathrm{IJ}$ concentration and lowest (86.7\%) at $500 \mathrm{IJs}$, although there were no significant differences between concentrations. Within $H$. downesi treatments highest mortality (56.7\%) occurred at 4000 IJs and lowest (43.3\%) at $500 \mathrm{IJs}$, but again within-species differences were not significant. Furthermore, in comparisons of all the EPN concentrations tested, the cumulative mortality of adult $\mathrm{H}$. abietis was higher at each day for $H$. abietis exposed to $S$. carpocapsae rather than to $H$. downesi (shown for 500 and $4000 \mathrm{IJ}$ concentrations in Fig. 1).

Probit analyses were conducted to calculate $\mathrm{LT}_{50}$ and $\mathrm{LT}_{90}$ values, in days, for each nematode at each concentration. Goodness of fit tests for each concentration showed that the Weibull distribution was the best fit to the data of all available distributions. Slopes of the lines did not differ significantly between EPN species for the $500 \mathrm{IJ}\left(\chi^{2}=3.8, \mathrm{df}=1, P=0.052\right), 2000 \mathrm{IJ}\left(\chi^{2}=2.3, \mathrm{df}=1\right.$, $P=0.13)$ and $4000 \mathrm{IJ}\left(\chi^{2}=1.3, \mathrm{df}=1, P=0.26\right)$ concentrations and therefore the comparisons of different EPN were similar, regardless of the day. However, for the 1000 IJ concentration the test for equal slopes was significantly different $\left(\chi^{2}=4.3, \mathrm{df}=1, P=0.04\right)$ and therefore the comparison of different nematodes against $H$. abietis will not be similar regardless of the time.

Overall, $\mathrm{LT}_{50}$ and $\mathrm{LT}_{90}$ values for all concentrations ranged between 2.99-4.07 days and 4.92-6.64 days, respectively, for $H$. downesi, and 3.49-4.52 days and 6.02-7.44 days, respectively, for $S$. carpocapsae (Table 1). At a concentration of 500 EPN the 95\% confidence intervals of $\mathrm{LT}_{50}$ and $\mathrm{LT}_{90}$ values did not overlap between $S$. carpocapsae and $H$. downesi, with the latter having significantly lower values. However, at higher concentrations all CI overlapped, indicating no significant differences in either $\mathrm{LT}_{50}$ or $\mathrm{LT}_{90}$ values between EPN species. Comparing $\mathrm{LT}_{50}$ and $\mathrm{LT}_{90}$ values for each concentration, within each nematode species, there were significant differences for S. carpocapsae between the 500 and 2000 IJ concentrations, for both $\mathrm{LT}_{50}$ and $\mathrm{LT}_{90}$ values, and between 1000 and 2000 IJ concentrations for $\mathrm{LT}_{50}$ values, in all cases with the $2000 \mathrm{IJ}$ concentration having significantly lower values. For $H$. downesi there were significant differences between the 500 and $1000 \mathrm{IJ}$ concentrations for both $\mathrm{LT}_{50}$ and $\mathrm{LT}_{90}$ values, with the $500 \mathrm{IJ}$ concentration having significantly lower values.

\subsection{Effects of EPN on feeding by adult $H$. abietis: bark disk experiment}

In both experiments there were no significant differences between treatments, both control and experimental, in the numbers 
Table 1

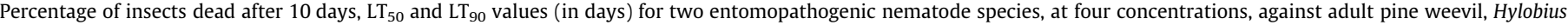
abietis. Percent mortality was compared between nematode species at each concentration by $\chi^{2}$ tests.

\begin{tabular}{|c|c|c|c|c|c|}
\hline Nematode species & EPN conc. (IJs insect ${ }^{-1}$ ) & Percent mortality at day 10 & & $\mathrm{LT}_{50} \pm \mathrm{SE}$ in days $(95 \% \mathrm{CI})$ & $\mathrm{LT}_{90} \pm \mathrm{SE}$ in days $(95 \% \mathrm{CI})$ \\
\hline H. downesi & 500 & 43.3 & $* * *$ & $\begin{array}{l}2.99 \pm 0.24 \\
(2.52-3.47)\end{array}$ & $\begin{array}{l}4.92 \pm 0.40 \\
(4.23-5.83)\end{array}$ \\
\hline S. carpocapsae & 500 & 86.7 & & $\begin{array}{l}4.52 \pm 0.23 \\
(4.04-4.95)\end{array}$ & $\begin{array}{l}7.44 \pm 0.34 \\
(6.83-8.22)\end{array}$ \\
\hline H. downesi & 1000 & 53.3 & * & $\begin{array}{l}4.07 \pm 0.25 \\
(3.57-4.56)\end{array}$ & $\begin{array}{l}6.64 \pm 0.38 \\
(5.96-7.48)\end{array}$ \\
\hline S. carpocapsae & 1000 & 83.3 & & $\begin{array}{l}4.37 \pm 0.22 \\
(3.92-4.79)\end{array}$ & $\begin{array}{l}7.12 \pm 0.34 \\
(6.51-7.90)\end{array}$ \\
\hline H. downesi & 2000 & 53.3 & $* * *$ & $\begin{array}{l}3.56 \pm 0.24 \\
(3.07-4.04)\end{array}$ & $\begin{array}{l}6.14 \pm 0.40 \\
(5.42-7.04)\end{array}$ \\
\hline S. carpocapsae & 2000 & 93.3 & & $\begin{array}{l}3.49 \pm 0.20 \\
(3.07-3.87)\end{array}$ & $\begin{array}{l}6.02 \pm 0.29 \\
(5.49-6.67)\end{array}$ \\
\hline H. downesi & 4000 & 56.7 & ** & $\begin{array}{l}3.71 \pm 0.23 \\
(3.25-4.18)\end{array}$ & $\begin{array}{l}6.16 \pm 0.38 \\
(5.49-7.02)\end{array}$ \\
\hline S. carpocapsae & 4000 & 90.0 & & $\begin{array}{l}3.94 \pm 0.21 \\
(3.51-4.33)\end{array}$ & $\begin{array}{l}6.54 \pm 0.30 \\
(5.99-7.21)\end{array}$ \\
\hline
\end{tabular}

${ }^{*} P<0.05$.

*** $P<0.01$.

${ }^{* * *} P=0.001$.

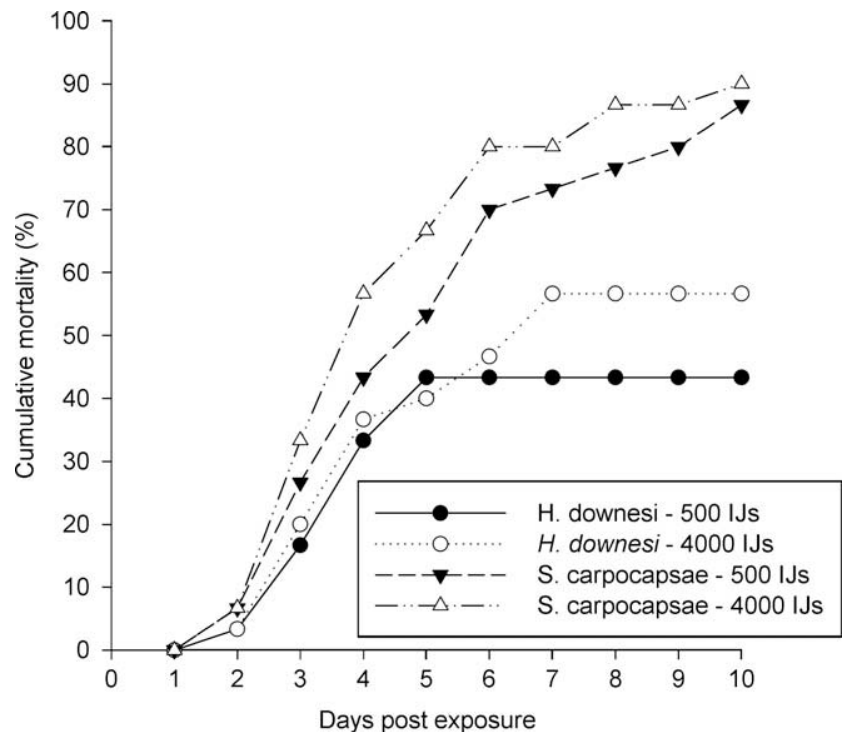

Fig. 1. Cumulative mortality of adult pine weevil, Hylobius abietis, exposed for $12 \mathrm{~h}$ to one of two concentrations (500 and $4000 \mathrm{IJs}$ insect ${ }^{-1}$ ) of Heterorhabditis downesi or Steinernema carpocapsae.

of weevils killed by nematodes (Table 2; Fig. 2A). Dissection of live and dead weevils at the end of each experiment showed which weevils had been invaded by nematodes. This allowed analysis of weevil feeding data to be conducted on either: (1) only infected weevils i.e. those weevils that at the end of the experiment contained live, dead or encapsulated nematodes on dissection (weevils could be both alive or dead at point of dissection) or (2) exposed weevils i.e. all weevils that had been exposed to nematodes. Dissection demonstrated that the pine weevils were capable of encapsulating both species of nematode (Fig. 2).

There were no significant differences between treatments in the percentage of surviving weevils, either infected (Table 3 ), or exposed (data not shown), which fed each day, for either of the two experiments. This indicated that neither EPN invasion nor exposure had an effect on a weevil's tendency to feed over a $24 \mathrm{~h}$ period, at any point, for up to a week after exposure. In general the percentage of weevils that fed increased from the first day onwards.

In the first experiment, when analyzing only weevils (live and dead) which had been infected by nematodes, the mean percentage weight loss from bark disks was significantly different between the six treatments $\left(F_{5,635}=43.17, P<0.001\right)$ (Fig. 3B), and also between the 5 days $\left(F_{4,635}=4.69, P=0.001\right)$ (Fig. $\left.3 A\right)$. However, there was no significant interaction between treatment and day $\left(F_{20,635}=0.77, P=0.75\right)$, therefore the values collected for each day and each treatment were pooled (Fig. 3). Mean percentage weight loss of bark decreased over the 5 day period, with weight loss significantly lower on the fourth and fifth days than on the first (Fig. $3 \mathrm{~A}$ ). In all treatments where weevils were present, weight loss was significantly higher than for the control treatment, without weevils (Fig. 3 B). The only significant difference between

Table 2

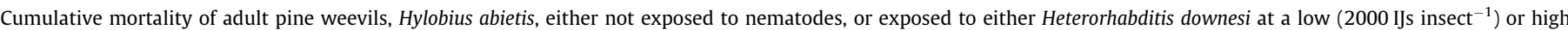

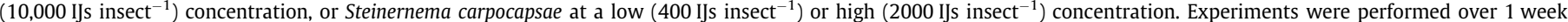

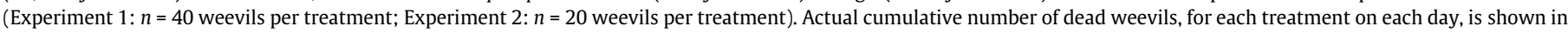
brackets.

\begin{tabular}{|c|c|c|c|c|c|c|}
\hline \multirow[t]{2}{*}{ Experiment } & \multirow[t]{2}{*}{ Days after exposure } & \multicolumn{5}{|c|}{ Cumulative\% (and no.) of $H$. abietis dead for each treatment } \\
\hline & & No nematodes & H. downesi low & H. downesi high & S. carpocapsae low & S. carpocapsae high \\
\hline \multirow[t]{3}{*}{1} & 1 & $0(0)$ & $2.5(1)$ & $10(4)$ & $5(2)$ & $15(6)$ \\
\hline & 2 & $2.5(1)$ & $2.5(1)$ & $12.5(5)$ & $10(4)$ & $22.5(9)$ \\
\hline & 5 & $2.5(1)$ & $5(2)$ & $12.5(5)$ & $12.5(5)$ & $22.5(9)$ \\
\hline \multirow[t]{3}{*}{2} & 1 & $0(0)$ & $0(0)$ & $0(0)$ & $5(1)$ & $0(0)$ \\
\hline & 2 & $0(0)$ & $10(2)$ & $25(5)$ & $15(3)$ & $10(2)$ \\
\hline & 6 & $5(1)$ & $25(5)$ & 45 (9) & $25(5)$ & $15(3)$ \\
\hline
\end{tabular}




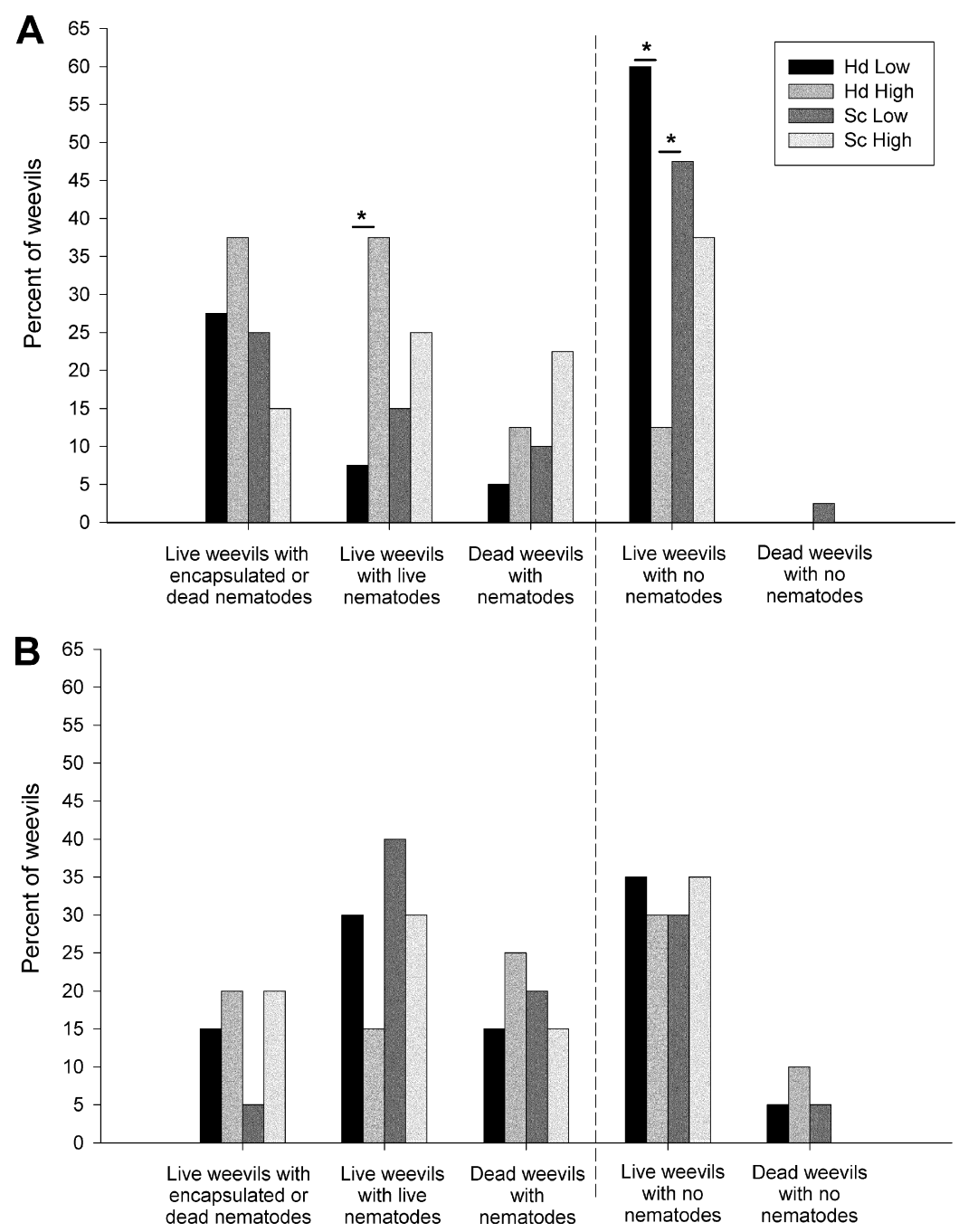

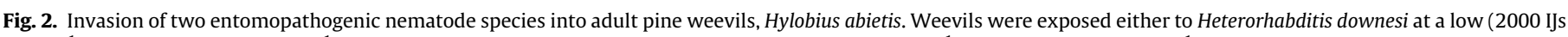

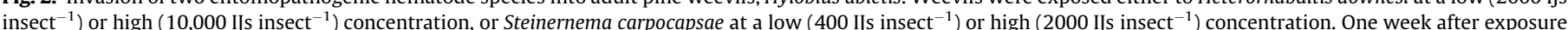

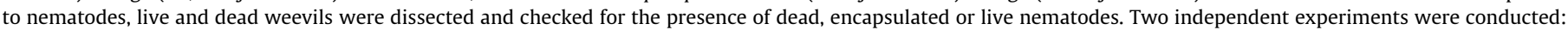
(A) $n=40$; and (B) $n=20$. Asterisks represent a significant difference at $P<0.05$ using $\chi^{2}$ tests with Bonferroni correction.

Table 3

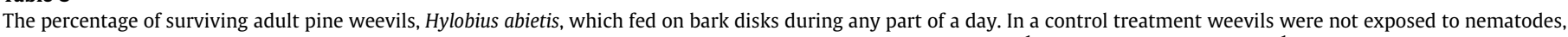

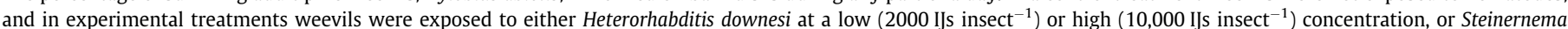

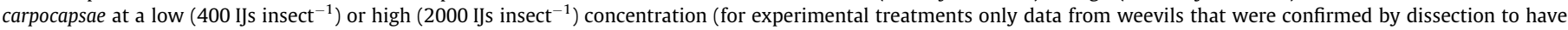
been infected by nematodes are shown in this table). Total numbers $(n)$ of surviving nematode-infected weevils, for each treatment on each day, are shown in brackets.

\begin{tabular}{|c|c|c|c|c|c|c|}
\hline \multirow[t]{3}{*}{ Experiment } & \multirow[t]{3}{*}{ Days after exposure } & \multicolumn{5}{|c|}{$\%$ of $H$. abietis feeding in each treatment (number of surviving weevils in brackets) } \\
\hline & & \multirow{2}{*}{$\begin{array}{l}\text { Control } \\
\text { No nematodes }\end{array}$} & \multicolumn{4}{|c|}{ Weevils infected by nematodes } \\
\hline & & & H. downesi low & H. downesi high & S. carpocapsae low & S. carpocapsae high \\
\hline \multirow[t]{3}{*}{1} & 1 & $60.0(40)$ & $53.3(15)$ & $57.1(35)$ & $35.0(20)$ & $76.0(25)$ \\
\hline & 2 & $60.0(40)$ & $60.0(15)$ & $54.8(31)$ & $77.8(18)$ & $84.2(19)$ \\
\hline & 5 & $89.7(39)$ & $100.0(14)$ & $90.0(30)$ & $87.5(16)$ & $100.0(16)$ \\
\hline \multirow[t]{3}{*}{2} & 1 & 15.8 (19) & $9.1(11)$ & $16.7(12)$ & $38.4(13)$ & $23.1(13)$ \\
\hline & 2 & 57.9 (19) & $45.5(11)$ & 41.7 (12) & $50.0(12)$ & $61.5(13)$ \\
\hline & 6 & 89.5 (19) & $77.8(9)$ & $85.7(7)$ & $85.7(7)$ & $77.8(9)$ \\
\hline
\end{tabular}

weevil treatments was that the weight loss of bark was significantly lower for the $S$. carpocapsae low concentration than the $H$. downesi high concentration $(P<0.05)$.

Analysis of all nematode exposed weevils, for the first experiment, mirrored the findings for infected weevils, with significant differences between all treatments $\left(F_{5,905}=52.47, P<0.001\right)$, and all days $\left(F_{4,905}=9.03, P<0.001\right)$ (data not shown), but no interac- tion between treatment and day $\left(F_{20,905}=1.04, P=0.41\right)$. Again, mean percentage weight loss of bark decreased over the 5 day period, with weight loss significantly lower on the fourth and fifth days than on the first. Weight loss was significantly higher for all weevil treatments than for the control treatment, but there were no differences between any of the weevil present treatments. The results for the two data sets (infected and exposed weevils), 

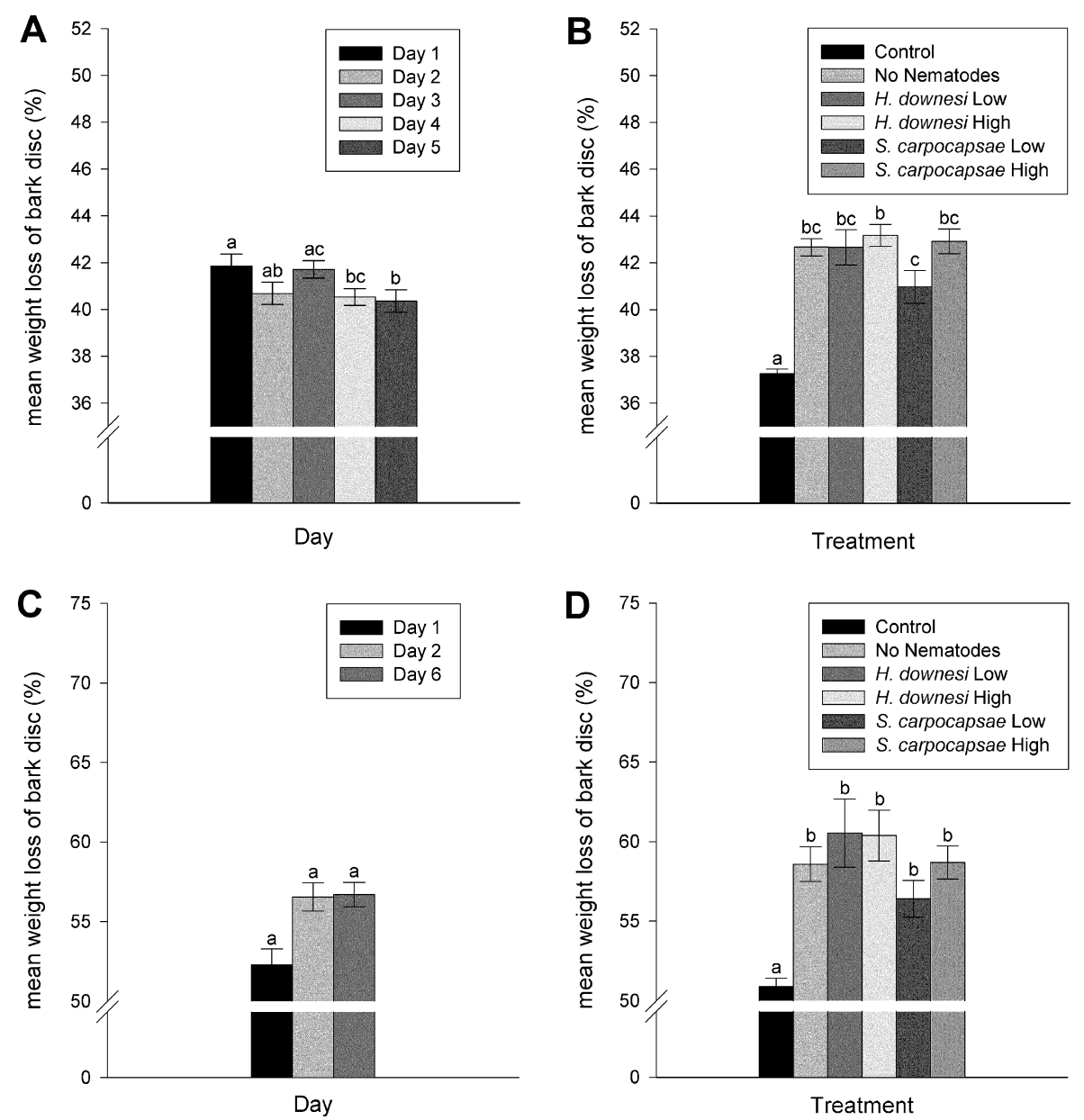

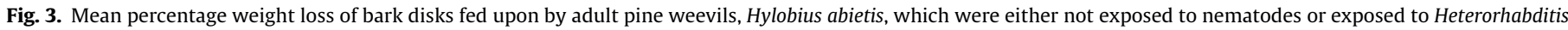

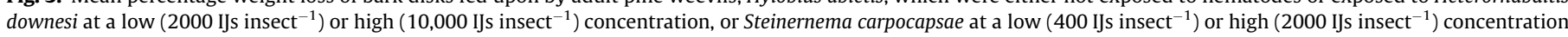

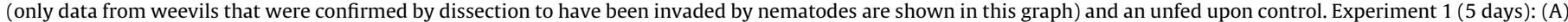

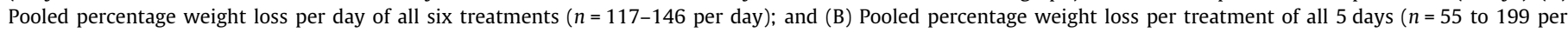

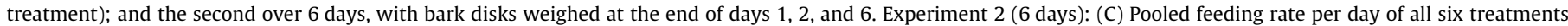

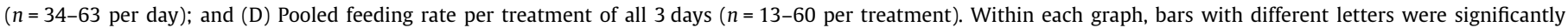
different by Tukey's tests to at least $P<0.05$.

suggest that neither infection with nor exposure to nematodes had an effect on weevil feeding rate, on any day, for the first week after infestation.

In the second experiment, for infected weevils only, there were significant differences between the six treatments $\left(F_{5,135}=13.03\right.$, $P<0.001$ ) (Fig. 3D), but not between the 3 days $\left(F_{2,135}=2.17\right.$, $P=0.12$ ) (Fig. $3 C$ ) and there was no interaction between treatment and day $\left(F_{10,135}=0.72, P=0.71\right)$. As in the previous experiment, in all treatments where weevils were present weight loss was significantly higher than for the control treatment, but there was no difference between any of the weevil present treatments. However, as in the first experiment, $S$. carpocapsae low concentration again showed the lowest bark weight loss. Comparisons of data for all weevils exposed to nematodes in the second experiment displayed similar results to those for nematode-infected: there were significant differences between all treatments $\left(F_{5,177}=15.66, P<0.001\right)$, but not between all days $\left(F_{2,177}=1.48, P=0.23\right)$, with no significant interaction between treatment and day $\left(F_{10,177}=0.72, P=0.71\right)$.

The majority of weevils that died in these experiments contained nematodes and, in addition, 35-75\% of live weevils also contained nematodes (Fig. 2). Live weevils either had dead and encapsulated nematodes or live ones, but not both. In the first experiment, there were significantly more live weevils containing live nematodes at the high, rather than the low concentration of
H. downesi (Fig. 2A). In the second experiment it was noted that 12 weevils from all nematode treatments had large numbers of IJs clumped under their elytra and that 11 of these weevils had also been invaded by nematodes.

\subsection{Effects of EPN on feeding by adult H. abietis: seedling experiment}

At the end of the experiment mortality of weevils was recorded at $8 \%$ in the control treatment, $14 \%$ in the S. carpocapsae treatments and $32 \%$ in the $H$. downesi treatments. The remaining live weevils were then incubated for 2 weeks to monitor subsequent death, in total $8 \%$ of control weevils died, $24 \%$ in the S. carpocapsae treatment and $44 \%$ in the $H$. downesi treatment, suggesting that a fair proportion of the weevils in the treatment had become infected.

Over 6 days, a single weevil consumed a mean of $1072 \pm$ $264 \mathrm{~mm}^{2}$ of bark, while three weevils consumed a mean of $2125 \pm 217 \mathrm{~mm}^{2}$. In total 23 seedlings had their entire bark stripped and the mean feeding area for these seedlings was $2155 \pm 130 \mathrm{~mm}^{2}$. Therefore, the mean feeding recorded for three weevils during the course of the experiment was on average equivalent to almost the entire seedling (given that seedling size had been standardized). The duration ( 6 days) of the experiment was too short for seedling death to be evident, but in all likelihood, given that stem girdling results in death, most if not all of the seedlings fed on in this 
experiment would eventually die. The area of bark consumed in the nematode treatments did not differ from that in the control treatments $(F=0.25 ; d f=2,120 ; P>0.05)$, but was affected by weevil density $(F=8.56 ; d f=1,120 ; P<0.01$; Fig. 4$)$. Within the nematode treatments, the area of bark consumed was affected by weevil den$\operatorname{sity}(F=14.86 ; d f=1,96 ; P<0.001)$, but not by nematode species or concentration $(F=2.89 ; d f=1,96 ; P>0.05$ and $F=0.51 ; d f=1,96$; $P>0.05)$. There was an interaction between nematode and concentration $(F=3.69 ; d f=2,96 ; P<0.05)$, but not between any of the other factors $(P>0.05)$. Therefore, these data also suggest that exposure to EPN had no effect on overall bark consumption by weevils.

\section{Discussion}

Currently, control of the large pine weevil by EPN involves applying large numbers of IJs to the soil around tree stumps, targeting all stages - larvae, pupae, and callow adults developing within the stump (Pye and Pye, 1985; Brixey, 2000; Brixey et al., 2006; Dillon et al., 2006, 2007; Torr et al., 2007). S. carpocapsae has been most widely used for this to date (Brixey, 2000; Brixey et al., 2006), but $H$. downesi consistently reduces number of adults to a greater extent (Dillon et al., 2006, 2007). Since nematodes kill at most $77 \%$ of the immature weevils (Dillon et al., 2007), inevitably a proportion will emerge from the stump as adults, posing a threat to newly planted seedlings. Furthermore, adults are less susceptible to EPN infestation than all other life stages (Pye and Burman, 1978; Dillon et al. 2007). Damage to seedlings could be reduced if adult weevils became infected as they emerged through nematode-infested soil and if such infection were to result in death and/or reduced feeding rate. Previously, S. carpocapsae has been trialed for direct protection of seedlings against $H$. abietis (Pye and Pye, 1985) and $H$. congener (Eidt et al., 1995); with this approach, nematodes are concentrated around the base of the seedling and so the weevil will only encounter them once it has reached its food supply; rapid kill and/or rapid cessation of feeding would in this case be even more critical in protecting seedlings from damage.

In our bioassay, immersion in nematode-infected soil for $12 \mathrm{~h}$ resulted in subsequent death of about half (43-57\%) of the weevils when the nematode was $H$. downesi, and nearly all of them

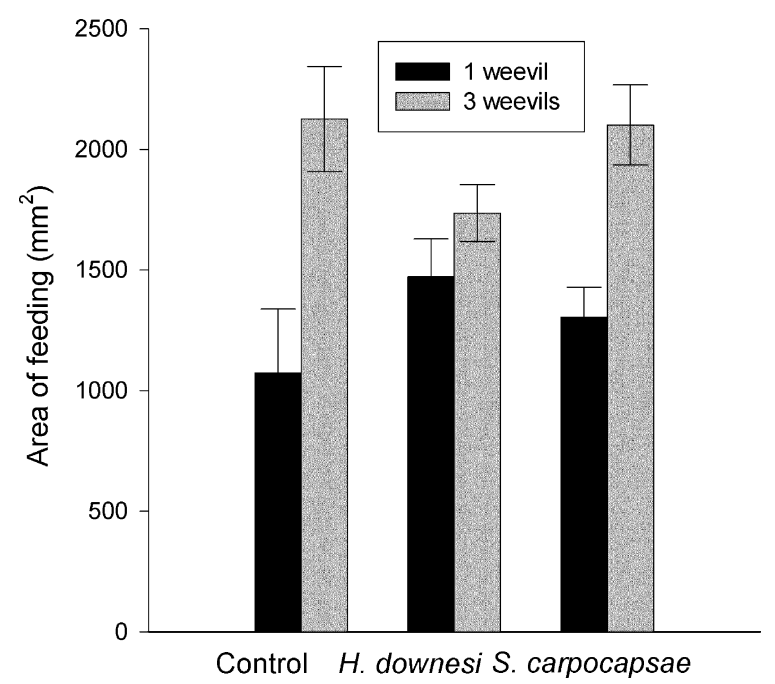

Fig. 4. The mean area of bark consumed by either one or three adult pine weevils, Hylobius abietis, on Sitka spruce seedlings that had been treated with entomopathogenic nematodes. Seedlings were treated with either Heterorhabditis downesi or Steinernema carpocapsae, and a control group of seedlings were not treated with nematodes. Weevils were allowed feed on the seedlings and the area of bark consumed was recorded after 6 days. (Control, $n=18 ; H$. downesi, $n=54 ; S$. carpocapsae, $n=54)$.
(83-93\%) when it was S. carpocapsae at comparable concentrations. Weevils continued to die for up to 10 days, despite the fact that they were no longer in contact with nematodes after the first day. As shown in the seedling experiment, one weevil feeding for 6 days can consume over $1000 \mathrm{~mm}^{2}$ of bark; more than enough to kill a young plant. The reason for the relatively long survival time after exposure to nematodes is not clear, but one possible explanation relates to the immune response mounted by the weevils against the nematodes. Encapsulation of IJs of both nematode species by adult $H$. abietis in the feeding assay demonstrated that the insects were capable of mounting an immune response against EPN. Encapsulation and melanisation of EPN is a common immune response amongst insects ( $\mathrm{Li}$ et al., 2007), and melanisation of $S$. carpocapsae by the larvae of $H$. abietis has previously been noted (Pye and Burman, 1977). A proportion of the insects dissected after 5-6 days in the feeding assay were alive but harbored encapsulated or dead nematodes: these weevils may have successfully defended themselves against the nematodes and might have survived had they not been sacrificed. However, a substantial proportion of live weevils sacrificed at this time harbored live nematodes instead. Li et al. (2007) noted that nematodes may escape from encapsulation, and this could explain both the finding of live nematodes within the weevils so long after exposure to nematodes, and also the delayed death of weevils following exposure. An alternative explanation for both of these phenomena is delayed entry by IJs into the host's body. In the feeding experiment, live IJs were found under the elytra of some weevils, providing a private source of infection through the spiracles several days after weevils were removed from the nematode-contaminated environment. Adult $H$. congener with both mouth and anus sealed still became infected with Steinernema spp. (Eidt et al., 1995), pointing to the spiracles as a route of entry into adult Hylobius.

In the bark feeding experiments, neither infection with, nor exposure to, either species of nematode had an effect on whether an adult $H$. abietis fed or not on a given day, nor on the average amount consumed; nor did weevil feeding rates decline over the 5-6 day period after exposure. Furthermore, the results of the seedling experiment showed that by the end of the experimental period weevil mortality was significantly higher in the $H$. downesi treatments than in the $S$. carpocapsae or control treatments, suggesting that weevil feeding pressure was higher in the control. Despite this fact, the area of bark consumed by weevils in the nematode treatments was not significantly lower than in the untreated control. These results indicate that both exposure to and infection with either species of nematode did not have an effect on their feeding rate or total bark consumption. Insects that are infected with a lethal concentration of EPN become less active as they approach death, and Alchanatis et al. (2000) demonstrated "pre-mortal" reduction in feeding rate of Spodoptera littoralis larvae; leaf consumption was reduced within hours of infection by Steinernema riobrave, although death did not occur until $48 \mathrm{~h}$ afterwards. We assume that pine weevil do, indeed, cease feeding at some point before they die, but acute "pre-mortal" feeding reduction was not detected in our study. Mortality during the experiment was relatively low (rarely exceeding $25 \%$ in any treatment), and only the consumption of weevils that had survived the previous 24-h feeding period was recorded, which may have been too long an interval to detect cessation of feeding shortly before death. However, the experiment was not designed to detect this immediate pre-death cessation of feeding. What our results show is that weevils that are fighting and/or succumbing to nematode infection do not reduce their food intake. However, these data do not rule out the possibility that sub-lethal infection by EPN may affect other behaviors in $\mathrm{H}$. abietis, for example their foraging behavior, i.e. whether they are able to locate seedlings or even their preferences for certain seedlings. Preference to plant host volatiles varies 
at different phases of the adult pine weevil life cycle (Nordenhem and Eidmann, 1991) and therefore may also be influenced by other factors. An insect's food choice may be influenced by the energetic and nutrient demands of mounting an immune response (Povey et al., 2009), possibly influencing choice of food plant.

The results of this study suggest that $S$. carpocapsae is a more effective nematode than $H$. downesi for killing adult $H$. abietis. This was confirmed in other experiments using different assay types, showing that it is not just a feature of the assay conditions. For example, in continuous exposure on filter paper, the $\mathrm{LC}_{50}$ for $\mathrm{H}$. downesi was approximately $200 \mathrm{IJs} /$ weevil, while for S. carpocapsae it was less than 50 (Ennis, unpublished data). The reasons for the superiority of $S$. carpocapsae over $H$. downesi in killing adult $H$. abietis (such as behavior of IJs, differential immune response of insect, suitability of nematode/bacterial pathogenicity factors for this host) are outside the scope of this study. Although $S$. carpocapsae kills more weevils than $H$. downesi, it does not kill them substantially faster. If considering nematodes for seedling protection, a species or strain with faster speed of kill would be desirable. Three weevils feeding for 6 days can completely strip the bark form a seedling; however, a seedling can be killed by much less weevil feeding pressure if it is girdled.

\section{Acknowledgments}

The work was funded by COFORD, the Irish National Council for Forest Research and Development, as part of the ABATE project. We thank the staff and summer students of the Biology Department, NUIM, for their assistance with laboratory experiments. We thank Coillte for provision of seedlings for experiments.

\section{References}

Alchanatis, V., Navon, A., Glazer, I., Levski, S., 2000. An image system for measuring insect feeding effects caused by biopesticides. J. Agr. Eng. Res. 77, 289-296.

Brixey, J.M., 2000. The use of entomopathogenic nematodes to control the immature stages of the large pine weevil, Hylobius abietis. $\mathrm{PhD}$ thesis, University of Reading, UK.

Brixey, J.M., Moore, R., Milner, A.D., 2006. Effect of entomopathogenic nematode (Steinernema carpocapsae Weiser) application technique on the efficacy and distribution of infection of the large pine weevil (Hylobius abietis L.) in stumps of Sitka spruce (Picea sitchensis Carr.) created at different times. Forest Ecol. Manage. 226, 161-172.

Campbell, J.F., Gaugler, R., 1993. Nictation behavior and its ecological implications in the host search strategies of entomopathogenic nematodes (Heterorhabditidae and steinernematidae). Behaviour 126, 155-169.

Dillon, A.B., Downes, M.J., Ward, D., Griffin, C.T., 2006. Suppression of the large pine weevil Hylobius abietis (L.) (Coleoptera: Curculionidae) in pine stumps by entomopathogenic nematodes with different foraging strategies. Biol. Control 38, 217-226.

Dillon, A.B., Ward, D., Downes, M.J., Griffin, C.T., 2007. Optimizing application of entomopathogenic nematodes to manage large pine weevil, Hylobius abietis L. (Coleoptera: Curculionidae) populations developing in pine stumps, Pinus sylvestris. Biol. Control 40, 253-263.

Eidmann, H.H., Nordenhem, H., Weslien, J., 1996. Physical protection of conifer seedlings against pine weevil feeding. Scand. J. Forest Res. 11, 68-75.

Eidt, D.C., Zervos, S., Finney-Crawley, J.R., 1995. Susceptibility of adults of Hylobius congener Dalle Torre, Shenkling and Marshall (Coleoptera: Curculionidae) to entomopathogenic nematodes. Can. Entomol. 127, 439-441.

Forst, S., Dowds, B., Boemare, N., Stackebrandt, E., 1997. Xenorhabdus and Photorhabdus spp.: bugs that kill bugs. Annu. Rev. Microbiol. 51, 47-72.

Georgis, R., Koppenhöfer, A.M., Lacey, L.A., Bélair, G., Duncan, L.W., Grewal, P.S., Samish, M., Tan, L., Torr, P., van Toll, R.W.H.M., 2006. Successes and failures in the use of parasitic nematodes for pest control. Biol. Control $38,103-123$.
Langstrom, B., Day, K.R., 2004. Damage control and management of weevil pests, especially Hylobius abietis. In: Lieutier, F., Day, K.R., Battisti, A., Gregoire, J.C. Evans, H.F. (Eds.), Bark and Wood Boring Insects in Living Trees in Europe, a Synthesis. Kluwer Academic Publishers, The Netherlands, pp. 415-444.

Leather, S.R., Day, K.R., Salisbury, A.N., 1999. The biology and ecology of the large pine weevil, Hylobius abietis (Coleoptera: Curculionidae): a problem of dispersal? Bull. Entomol. Res. 89, 3-16.

Li, X.Y., Cowles, R.S., Cowles, E.A., Gaugler, R., Cox-Foster, D.L., 2007. Relationship between the successful infection by entomopathogenic nematodes and the host immune response. Int. J. Parasitol. 37, 365-374.

Lynch, A.M., 1984. The pales weevil, Hylobius pales (Herbst.): a synthesis of the literature. J. Geo. Entomol. Soc. 19, 1-34.

Martin, J.L., 1964. The insect ecology of red pine plantations in central Ontario. II. Life history and control of Curculionidae. Can. Entomol. 96, 1408-1417.

Mràcek, Z., Hanzal, R., Kodrik, D., 1988. Sites of penetration of juvenile steinernematids and heterorhabditids (Nematoda) into the larvae of Galleria mellonella (Lepidoptera). J. Invertebr. Pathol. 52, 477-478.

Nordenhem, H., 1989. Age, sexual development and seasonal development of the pine weevil Hylobius abietis (L). J. Appl. Entomol. 108, 260-270.

Nordenhem, H., Eidmann, H.H., 1991. Response of the pine weevil Hylobius abietis L. (Col., Curculionidae) to host volatiles in different phases of its adult life cycle. J. Appl. Entomol. 112, 353-358.

Nordenhem, H., Nordlander, G., 1994. Olfactory oriented migration through soil by root-living Hylobius abietis (L.) larvae (Col., Curculionidae). J. Appl. Entomol. 117, 457-462.

Nordlander, G., 1987. A method for trapping Hylobius abietis (L.) with a standardized bait and its potential for forecasting seedling damage. Scand. J. Forest Res. 2, 199-213.

Nordlander, G., Nordenhem, H., Bylund, H., 1997. Oviposition patterns of the pine weevil Hylobius abietis. Entomol. Exp. Appl. 85, 1-9.

Orlander, G., Nilsson, U., 1999. Effect of reforestation methods on pine weevil (Hylobius abietis) damage and seedling survival. Scand. J. Forest Res. 14, 341354.

Peters, A., Ehlers, R.-U., 1994. Susceptibility of leatherjackets (Tipula paludosa and Tipula oleracea; Tipulidae: Nematocera) to the entomopathogenic nematode Steinernema feltiae. J. Invertebr. Pathol. 63, 163-171.

Petterson, M., Orlander, G., Nordlander, G., 2005. Soil features affecting damage to conifer seedlings by the pine weevil Hylobius abietis. Forestry 1, 83-92.

Poinar, G.O., 1979. Nematodes for Biological Control of Insects. CRC Press, Boca Raton, Florida, USA.

Povey, S., Cotter, S.C., Simpson, S.J., Lee, K.P., Wilson, K., 2009. Can the protein costs of bacterial resistance be offset by altered feeding behaviour? J. Anim. Ecol. 78 437-446.

Pye, A.E., Burman, M., 1977. Pathogenicity of the nematode Neoaplectana carpocapsae (Rhabditida, Steinernematidae) and certain microorganisms towards the large pine weevil, Hylobius abietis (Coleoptera, Curculionidae) Ann. Entomol. Fenn. 43, 115-119.

Pye, A.E., Burman, M., 1978. Neoaplectana carpocapsae: infection and reproduction in large pine weevil larvae, Hylobius abietis. Exp. Parasitol. 46, 1-11.

Pye, A.E., Pye, N.L., 1985. Different applications of the insect parasitic nematode Neoaplectana carpocapsae to control the large pine weevil, Hylobius abietis. Nematologica 31, 109-116.

Rose, D., Matthews, G.A., Leather, S.R., 2006. Sub-lethal responses of the large pine weevil, Hylobius abietis, to the pyrethroid insecticide lambda-cyhalothrin. Physiol. Entomol. 31, 316-327.

Scott, T.M., King, C.J., 1974. The large pine weevil and black pine beetles. Forestry Commission Leaflet No. 58, pp. 2-12.

Simões, N., Caldas, C., Rosa, J.S., Bonifassi, E., Laumond, C., 2000. Pathogenicity caused by high virulent and low virulent strains of Steinermena carpocapsae to Galleria mellonella. J. Invertebr. Pathol. 75, 47-54.

Solbreck, C., 1980. Dispersal distances of migrating pine weevils, Hylobius abietis, Coleoptera: Curculionidae. Entomol. Exp. Appl. 28, 123-131.

Tilles, D.A., Nordlander, G., Nordenhem, H., Eidmann, H.H., Wassgren, A., Bergstrom, G., 1986. Increased release of volatiles from feeding scars: a major cause of field aggregation in the pine weevil Hylobius abietis (Coleoptera: Curculionidae) Environ. Entomol. 15, 1050-1054.

Torr, P., Heritage, S., Wilson, M.J., 2007. Steinernema kraussei, an indigenous nematode found in coniferous forests: efficacy and field persistence against Hylobius abietis. Agric. Forest Entomol. 9, 181-188.

Willoughby, I., Evans, H., Gibbs, J., Pepper, H., Gregory, S., Dewar, J., Nisbet, T., Pratt, J., McKay, H., Siddons, R., Mayle, B., Heritage, S., Ferris, R., Trout, R., 2004 Reducing Pesticide Use in Forestry - Practical Guide. The Forestry Commission, pp. 25-29.

Woodring, J.L., Kaya, H.K., 1988. Steinernematid and Heterorhabditid Nematodes: A Handbook of Techniques. Southern Cooperative Series, Bulletin 331. Arkansas Agricultural Experiment Station. Fayetteville, Arkansas. 